\title{
A Phytochemical Approach to Synthesize Silver Nanoparticles for Non-Toxic Biomedical Application and Study on their Antibacterial Efficacy
}

\author{
Pratyusha Banerjee, and Debjani Nath* \\ Cytogenetics \& Molecular Biology Laboratory, Department of Zoology, University of Kalyani, West Bengal, India
}

Received: March 28, 2015; Accepted: March 14, 2015; Published: March 30, 2015

*Corresponding author: Debjani Nath, Cytogenetics \& Molecular Biology Laboratory, Department of Zoology, University of Kalyani, Kalyani-741235, Nadia, West Bengal, India, Tel: +033-2582-8750, E-mail: nath_debjani@yahoo.co.in

\begin{abstract}
Phytochemical approach of silver Nanoparticles (NPs) synthesis has been of great interest because of its environmental friendly potential nontoxic biomedical applications. The aim of this study was to synthesize silver nanoparticles using bark extract of Saraca asoca as reducing agent at an ambient temperature of $45^{\circ} \mathrm{C}$. The variables of the green synthesis route such as $\mathrm{pH}$, temperature, molar ratio of the reductants and duration of reaction time were optimized. UV-V is absorption spectroscopy showed the characteristic plasmon at approximately $433 \mathrm{~nm}$. The average range of particle size calculated using Dynamic Light Scattering measurements (DLS) was found to be 3-10 nm. AFM analysis showed the presence of almost spherical shaped particles within the size range of 2 to $10 \mathrm{~nm}$ with higher concentration of the extract. FT-IR analysis indicated the involvement of carboxyl $(-\mathrm{C}=0)$, hydroxyl $(-\mathrm{OH})$ and amine $(-\mathrm{NH})$ functional groups of the phytochemical present in $S$. asoca bark extract in reducing, capping and stabilizing silver nanoparticles. The GC-MS analysis revealed the presence of phyto-components bearing these groups in aqueous extract of bark and the prevailing compounds were Dibenzoyl-Ltartaric acid, 2,4-Di-tert-butylphenol, 2,4-Dichloro-6-phenyl-1,3,5triazine. The rapid electrokinetic behavior of the silver was evaluated using zeta potential (approx $-23.2 \mathrm{mV}$ ). The potential toxicological effect of these particles has been studied using in vivo mouse model. No significant level of toxicity was observed. Antimicrobial study was performed with Staphylococcus aureus, Escherichia coli, Pseudomonas aeruginosa, and Bacillus subtilis, Staphylococcus aureus and Bacillus subtilis showed highest sensitivity towards silver nanoparticles.
\end{abstract}

Keywords: Phytochemicals; Silver nanoparticle; Green synthesis; Characterization; Biomedical

\section{Introduction}

Over the past decade there has been an increased interest on the topic of "green" chemistry. A comprehensive review regarding greener nanosynthesis was presented by Bastys et.al and Zhang et.al $[1,2]$. By combining with Green Chemistry Principles nanotechnology is developing towards achieving the maximum benefit of nanoproducts for society and the environment in a nontoxic way [3-6].

Silver nanoparticles are one of the most commonly utilized nanomaterial in medical biology due to their high electrical and thermal conductivity, optical properties as well as anti-microbial properties [7-12]. It is an established fact that silver compounds are very effective as antibacterial agents for both aerobic and anaerobic strains of bacteria. The reason behind the superior antibacterial properties of Ag NPs is due to the formation of free radicals from the surface of Ag and subsequent free radical induced membrane damage [13-21]. In the field of therapeutics, silver nanoparticles has been widely and commonly used as an important agent for wound healing probably through collagen alignment $[22,23]$.

Medicinal plants are considerably useful and economically essential. They contain active constituents that are used in the treatment of many human diseases [24]. Among the various categories of compounds synthesized in plants, phytochemicals (primary and secondary metabolism products, such as antioxidants, flavonoids, flavones, isoflavones, catechins, anthocyanidins, isothiocyanates, carotenoids, and polyphenols) are the most potent materials for biological activities and are known as important natural resources for the synthesis of metallic nanoparticles [25]. In plant bioaccumulation, the localization of nanoparticles is based on the presence of particular enzymes or proteins involved in it. The recovery of these nanoparticles from plant tissues is tedious and expensive and needs enzymes to degrade the cellulosic materials, which surrounds it [26]. Thus, the synthesis of various metal nanoparticles using plant extracts is easy in downstream processing and in scaling up of nanoparticles [27-32].

Saraca asoca (Roxb.), one of the folk medicinal plants found in India, Bangladesh and Sri Lanka, belongs to family Caesalpiniaceae. A large number of primary and secondary metabolites like flavonoids, terpenoids, saponins, phenol, tannin, lignin, cardiac glycosides, and proteins are present in different parts of the plant [33]. The bark of Ashoka tree is used as antihypertensive in Dysmenorrhoea. It is haemorrhoidic, menorrhagic, leucorrhoeic, hemostatic, anticonvulsant and diuertic. It is also useful in menorrhagia due to uterine fibroids, in leucorrhea and in internal bleeding $[34,35]$. 
In the present study an attempt has been made for the synthesis of silver nanoparticles by reducing the silver ions in solution of silver nitrate with aqueous bark extract of Saraca asoca. The phytochemicals-coating of the surface of green nanomaterials was characterized and were tested for toxicity in mouse model and for their antimicrobial efficacy in vitro.

\section{Materials and Methods \\ Preparation for bark extract}

S. asoca bark was harvested during the month of midFebruary to mid-March. The authenticity of $S$. asoca was confirmed by eminent taxonomists using standard methods. Pieces of bark were completely air-dried at room temperature. They were kept away from direct sun light to avoid destruction of active compounds. The bark pieces were pounded to powder using metallic motor and pestle. Powder was stored at room temperature for further use.

\section{Extraction of plant material}

$2.5 \mathrm{~g}$ of powder were taken into $250 \mathrm{ml}$ conical flask, added with $100 \mathrm{ml}$ of sterile distilled water and boiled for 10 minutes at $100^{\circ} \mathrm{C}$. The bark extract was collected in separate conical flask by standard filtration method and half of the extract was stored at $4^{\circ} \mathrm{C}$ for synthesis of silver nanoparticles. Remaining half of the aqueous bark extract was reduced to minimum volume by evaporation in water bath and again dissolved in methanol for GC-MS analysis.

\section{GC-MS analysis of the plant material for active compounds}

The gas chromatography mass spectrometry (GC-MS) analysis of the extracts was performed using a GC-MS (QP 2010 series, Shimadzu, Tokyo, Japan) equipped with a ZV 5 silica capillary column of $30 \mathrm{~m}$ length, $0.25 \mathrm{~mm}$ diameter and $0.25 \mu \mathrm{m}$ film thickness. The analysis was done using ion trap technique operating in electron impact mode at $70 \mathrm{eV}$; helium (99.999\%) was used as carrier gas. An injection volume of $1 \mu \mathrm{l}$ was employed (split ratio of $10: 1$ ) injector temperature $250^{\circ} \mathrm{C}$; ion-source temperature $220^{\circ} \mathrm{C}$. The oven temperature was programmed from $60^{\circ} \mathrm{C}$ (isothermal for $2 \mathrm{~min}$ ), with an increase of $10^{\circ} \mathrm{C}$ / $\min$, to $110^{\circ} \mathrm{C}$, then $5^{\circ} \mathrm{C} / \mathrm{min}$ to $260^{\circ} \mathrm{C}$, ending with a $10 \mathrm{~min}$ isothermal at $260^{\circ} \mathrm{C}$. Mass spectra were taken at $70 \mathrm{eV}$; a scan interval of 0.5 seconds and fragments from 40 to $450 \mathrm{Da}$. Total GC running time is 49 mins.

The plant extract was dissolved in methanol [1:10] and filtered with HPLC method and analyzed in GC-MS for different components. Identification of Components Interpretation on mass spectrum GC-MS was conducted using the database of National Institute Standard and Technology (NIST) having more than 62,000 patterns. The spectrum of the unknown component was compared with the spectrum of the known components stored in the NIST library. The name, molecular weight and structure of the components of the test materials were ascertained.

\section{Green synthesis of nanoscale silver (Ag) particles}

$1 \mathrm{mM} \mathrm{AgNO}_{3}$ solution was prepared and stored in amber colored bottle. $50 \mathrm{ml}$ of $1 \mathrm{mM} \mathrm{AgNO}$, solution was taken in three conical flasks separately and added with the bark extract at different volume i.e. $75 \mu \mathrm{l}, 1.5 \mathrm{ml}$ and $3 \mathrm{ml}$ with constant stirring. The solutions were then heated on a water bath at different temperature ranging from $25^{\circ} \mathrm{C}-85^{\circ} \mathrm{C}$. The solutions were heated at $25^{\circ} \mathrm{C}, 45^{\circ} \mathrm{C}, 65^{\circ} \mathrm{C}$ and $85^{\circ} \mathrm{C}$ for 45 minutes and the change of color of the solution was observed. The change of color of the aqueous silver nitrate solution after addition of bark extract from pale yellow to dark brown indicated the synthesis of silver nanoparticles. ' $\lambda$ ' max of each sample was determined after 30 minutes of incubation at room temperature at complete dark using UV-visible spectrophotometer. The conical flask was incubated at room temperature for 48 hours. After complete settlement of nanoparticles the mixture was centrifuged at 10,000 rpm for 15 minutes. The supernatant was discarded and the pellet was collected and washed thoroughly with distilled water. The material was cleansed with water and ethanol alternately to obtain Ag powder. The preparation of nanoparticles was stored at $4^{\circ} \mathrm{C}$ until further use.

\section{UV-visible spectral analysis}

The synthesis of silver nanoparticles was monitored by a UV-visible spectrophotometer (Shimadzu, UV-2550, and Japan). For the analysis of the reaction mixture $0.1 \mathrm{ml}$ of the sample was diluted with $2 \mathrm{ml}$ of de-ionized water and the UV-visible spectrum of the resulting solution was monitored at every interval of $1 \mathrm{~nm}$.

\section{Particle size (DLS) analysis}

The particle size distribution of silver nanoparticles was evaluated using dynamic light scattering (DLS) measurements conducted with a Malvern Zetasizer Nanoseries compact scattering spectrometer (Malvern Instruments Ltd, Malvern, UK). Data were analyzed using Zetasizer software.

\section{AFM analysis}

For AFM imaging $10 \mu \mathrm{l}$ of the silver nanoparticles was deposited onto freshly cleaved muscovite Ruby mica sheet (ASTM V1 Grade Ruby Mica from MICAFAB, Chennai) for 15-30 mins. Mica sheets are basically negatively charged so that nanomaterial binds strongly on the mica surface. The sample was dried by using vacuum dryer after $15 \mathrm{~min}$. AAC mode AFM was performed using a Pico plus 5500 ILM AFM (Agilent Technologies USA) with a piezo scanner maximum range of $9 \mu \mathrm{m}$. Micro fabricated silicon cantilevers of $225 \mu \mathrm{m}$ in length with a nominal spring force constant of 21-98 N/m were used from nanosensors, USA. Cantilever oscillation frequency was tuned into resonance frequency at $150-300 \mathrm{kHz}$. The images ( 256 by 256 pixels) were captured with a scan size of 10 to 200 nanometer at the scan speed rate of 0.5 lines/ Sec. Images were processed by flatten using Pico view1.12 version software (Agilent Technologies, USA). Image manipulation has been done through Pico Image Advanced version software (Agilent Technologies, USA).

\section{Zeta Potential}

Zeta potential of Ag NPs was measured according to Tantra, et.al with the help of Zetasizer Nano ZS (Malvern) and a titrator MPT-2. Before the measurement, aqueous suspension of silver 
nanoparticles was filtered through a $0.45 \mu \mathrm{m}$ PTFE membrane. The zeta potential was calculated by the help of the software.

\section{FTIR analysis}

Perkin-Elmer spectrometer FTIR Spectrum in the range $4000-400 \mathrm{~cm}^{-1}$ at a resolution of $4 \mathrm{~cm}^{-1}$ was used for the analysis. The sample was mixed with $\mathrm{KBr}$ crystals. Thin sample disc was prepared by pressing with the disc preparing machine and placed in Fourier Transform Infrared [FTIR] for the analysis of the nanoparticles as well as for the bark powder.

\section{Acute oral toxicity test}

Experimental animals: All laboratory animals were purchased from a reputed breeder and were kept in stainless steel wire cages (Tarsons, India), maintained on 12 hour lightdark cycle. Along with pellet diet (West Bengal Diary and Poultry development corp. Ltd., Kalyani Industrial Area, Kalyani), ad libitum water was provided throughout the study. Fifteen male and 15 female ICR mice (10-12 weeks old, 25-32 g body weight) were used for the acute oral toxicity test. The animals were kept and maintained under 12:12 hr light-dark cycle, temperature of $24 \pm 1^{\circ} \mathrm{C}$, relative humidity of $55 \pm 10 \%$ and negative atmospheric pressure.

Acute toxicity study: Using the up and down procedure the acute oral toxicity of colloidal Ag NPs was tested in mice [36]. At a dose of 5,000 mg/ kg, colloidal AgNPs was administered orally in the mice of either sex. The animals were then observed continuously for determination of any toxic symptoms for first 3 $\mathrm{hr}$ after AgNPs administration. Finally, after 24 hours the number of survived mice was counted and animals were then maintained for 14 days for further observation. At 1, 7 and 14 days after gavages, five mice in each group were sacrificed.

Hematological analysis: For hematological analysis whole blood was collected from the experimental group of mice and different clinical parameters including Serum Glutamic Oxaloacetic Transaminase (SGOT), Serum Glutamic Pyruvic Transaminase (SGPT), serum creatinine, triglyceride, and total protein was tested.

Histopathological analysis: Major organs such as liver, kidney, spleen and heart were collected by sacrificing animals (three animals from each group were selected randomly) for histopathological analysis. The samples were then fixed immediately in $10 \%$ formal saline. Collected tissues were then dehydrated in graded concentrations of xylene and embedded in molten paraffin wax. Tissues were then sectioned at $5 \mathrm{~m}$ thick. Tissue sections were fixed on glass slides and stained with hematoxylin and eosin for microscopic observation.

Assay of bactericidal activity: Bactericidal activity of the AgNPs was appraised by the standard disc diffusion method with $6 \mathrm{~mm}$ diameter Whatman No.1 filter paper discs [37]. Metallic nanoparticles have bactericidal properties and exhibit increased chemical activity. This is due to their large surface to volume ratios and crystallographic surface structure. In this method 10 $\mu \mathrm{l}, 25 \mu \mathrm{l}$ and $50 \mu \mathrm{l}$ of silver nanoparticles (suspension of $1 \mathrm{mg} /$ $\mathrm{ml}$ ) prepared from bark extract was added with $1 \mathrm{ml}$ of distilled water and applied to sterile paper discs of $6 \mathrm{~mm}$ diameter. Standard antibiotic discs (ampicillin and tetracycline $10 \mathrm{mg} / \mathrm{ml}$ ) were used for control. Nutrient agar and LB agar was used for the antimicrobial test. Before the antibacterial assay the bacteria Escherichia Coli and Pseudomonas aeruginosa (gram negative bacteria); Bacillus subtilis and Staphylococcus aureus (gram positive bacteria) were inoculated into the LB and nutrient agar medium respectively and agar plates are incubated at $37^{\circ} \mathrm{C}$ for 24 hours. Inhibition of zone was measured after 24-48 hour of inhibition.

Statistical analysis: Results from Table 3, 4 and 5 were presented as mean \pm Standard Deviation (SD). Data were analyzed using analysis of variance (ANOVA; Tukey' Multiple Comparison Method). Values of $P<0.05$ were considered as the level statistical significance. Statistical analysis was performed using the SPSS statistical software.

\section{Results and Discussion}

\section{Analysis of phyto-components in aqueous bark extract of Saraca asoca by GC-MS}

Ten major compounds were identified by GC-MS analysis in aqueous bark extract of Saraca asoca. The active principles with their retention time (RT), molecular formula, molecular structure, molecular weight (MW) and concentration (\%) were analyzed. The prevailing compounds were (-)- dibenzoyl-L-tartaric acid, Phenol,2,4-di-tert-butyl-, 1,3,5-triazine,2,4-dichloro-6-phenyl as shown in table 1 and the corresponding chemical shift peaks of the spectrum were shown in [Figure 1]. The peak list with number of detected peaks has been shown in table 2 .

It is well known that the silver nanoparticles in aqueous colloidal solution exhibit yellowish brown color due to excitation of surface plasmon variation in silver nanoparticles. As the bark extract of Saraca asoca was mixed with aqueous solution of silver nitrate it started to change from pale yellow to reddish brown color due to reduction of silver ions indicating the formation of silver nanoparticles. Reduction of silver ion and the change in color has been frequently observed by several authors who successfully synthesized silver nanoparticles using different biomaterial [38-40]. In case of control experiment where bark extract was not added to silver nitrate solution exhibited no change in color even left for one week duration.

\section{UV-vis Spectrophotometry}

The molar ratio between $\mathrm{AgNO}_{3}$ and reductants was closely related with Ag-NPs formation, as observed through the difference of FWHM (full width at half maximum). However, the major reason of using excess reductants $(3 \mathrm{ml})$ was to ensure the complete reduction of all $\mathrm{Ag}^{+}$cations to metallic $\mathrm{Ag}$ [Figure $2 \mathrm{~A}]$. The specificity of reaction condition made this process a unique phytofabrication procedure. It was observed by several other investigators that the absorption maxima of colloidal silver solution was between 410 to $440 \mathrm{~nm}$ which was assigned to surface plasmon of various metal nanoparticles [41]. Scanning of absorption spectra of the mixture was continually recorded for one month time period, yielded no significant change in the 
Table 1: List of phyto-constituents in aqueous bark extract of Saraca asoca.

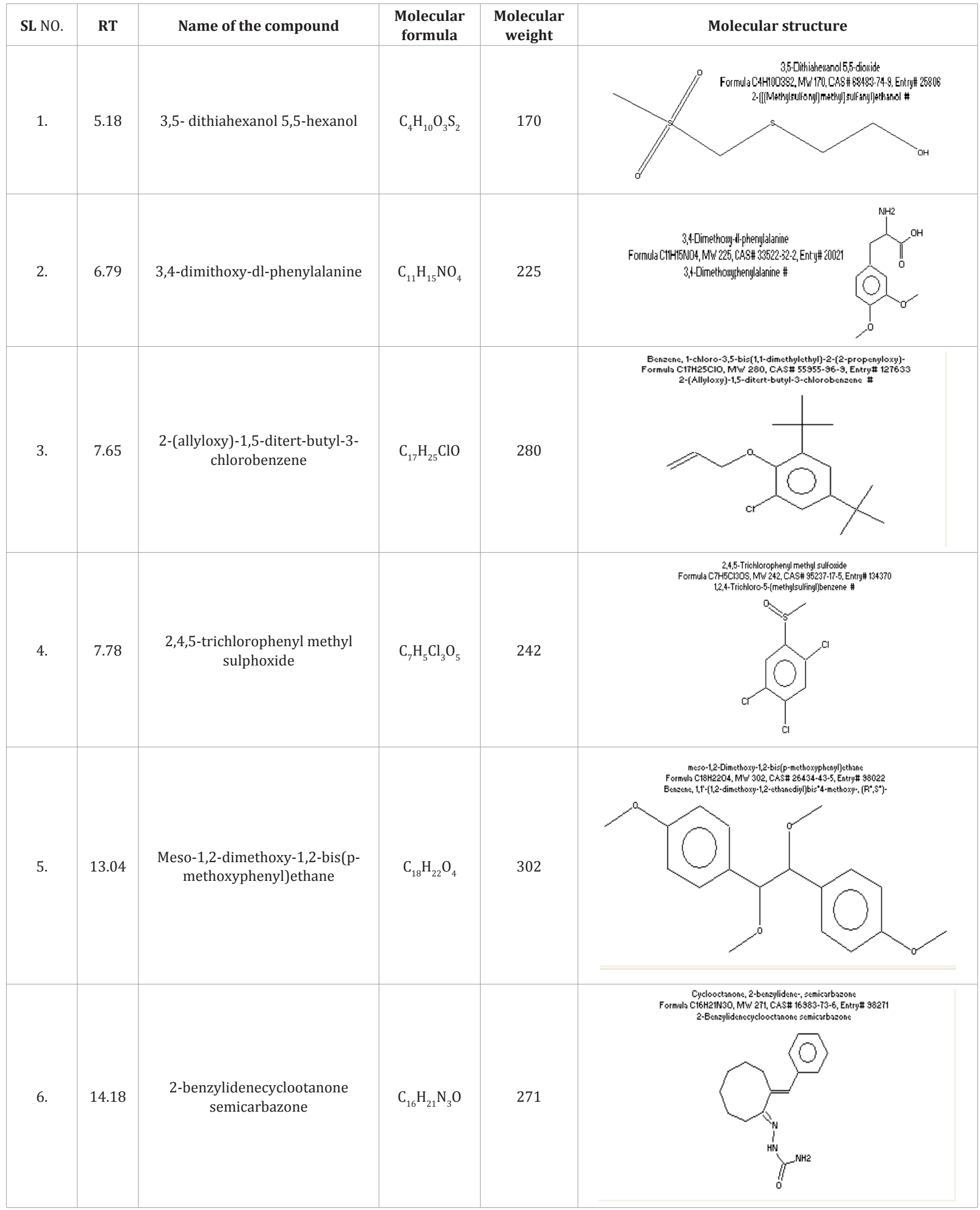




\begin{tabular}{|c|c|c|c|c|c|}
\hline 7. & 16.56 & $\begin{array}{c}\text { 1,3-dioxolane, 2-(5,5,5-trichloro-3- } \\
\text { penten-1-yl)-, (E)- }\end{array}$ & $\mathrm{C}_{8} \mathrm{H}_{11} \mathrm{Cl}_{3} \mathrm{O}_{2}$ & 244 & 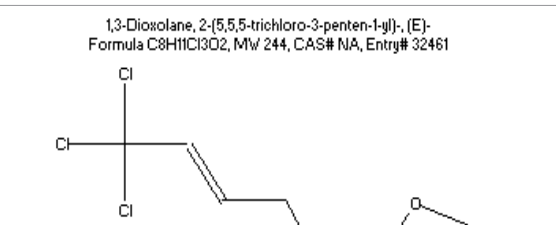 \\
\hline 8. & 18.58 & $\begin{array}{l}\text { 1,3,5-triazine,2,4-dichloro-6- } \\
\text { phenyl- }\end{array}$ & $\mathrm{C}_{9} \mathrm{H}_{5} \mathrm{Cl}_{2} \mathrm{~N}_{3}$ & 225 & 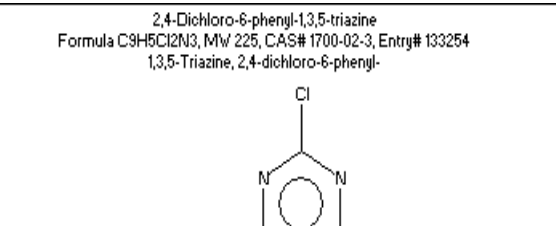 \\
\hline 9. & 24.16 & Phenol,2,4-di-tert-butyl- & $\mathrm{C}_{14} \mathrm{H}_{22} \mathrm{O}$ & 206 & 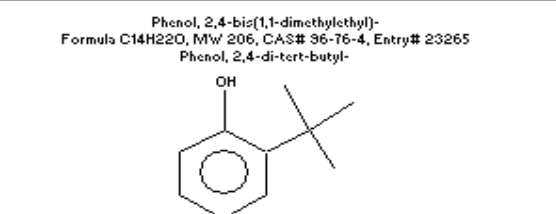 \\
\hline 10. & 25.71 & (-)-dibenzoyl-L-tartaric acid & $\mathrm{C}_{18} \mathrm{H}_{14} \mathrm{O}_{8}$ & 358 & 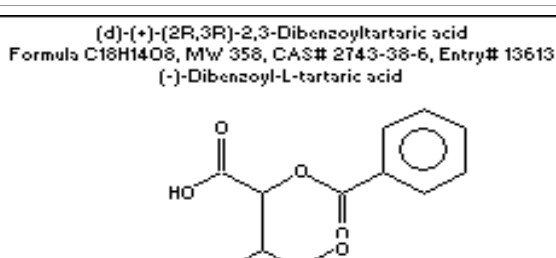 \\
\hline
\end{tabular}

Table 2: Peak List Of GC-MS Column.

\begin{tabular}{|c|c|c|c|c|}
\hline End RT & Area & \%Area & Height & \%Height \\
\hline 2.26 & 399310 & 75.64 & 270635.1 & 86.18 \\
\hline 2.65 & 66263.98 & 12.55 & 29615.1 & 9.43 \\
\hline 5.2 & 8022.362 & 1.52 & 5737.496 & 1.83 \\
\hline 24.35 & 49274.05 & 9.33 & 4967.284 & 1.58 \\
\hline 45.33 & 5021.332 & 0.95 & 3064.413 & 0.98 \\
\hline
\end{tabular}

intensity of absorption maxima suggesting stable nanoparticle formation.

It is generally recognized that UV-Visible spectroscopy could be used to examine the size and shape of nanoparticles in aqueous solution $[42,43]$. The reduction of silver ions and formation of stable nanoparticles occurred in a concentration as well as temperature dependent reaction. Because of the instability of synthesized silver nanoparticles an optimum temperature is needed for the completion and settlement of the reduction reaction. It was observed that the optimal temperature of reaction mixture for conversion was $45^{\circ} \mathrm{C}$ and the SPR peaks became sharper with increase in optical density of the yellowish brown solution after 30 min of stirring depending on increasing temperature from $25^{\circ} \mathrm{C}$ to $45^{\circ} \mathrm{C}$ [Figure 2B,2C]. The absorption band at $433 \mathrm{~nm}$ showed the formation of silver 
Table 3: Hematological parameters of mice of different day groups after treatment with colloidal AgNPs.

\begin{tabular}{|c|c|c|c|c|c|c|c|c|c|c|c|c|}
\hline Day & Group & RBC & $\mathbf{H b}$ & Ht & MCV & $\mathrm{MCH}$ & МСHC & PLT & WBC & Lymp & Mono & Granular \\
\hline & & $(\times 106)$ & (g/dl) & (\%) & $(\times m-3)$ & (pg) & $(\mathrm{g} / \mathrm{dl})$ & $\begin{array}{l}(\times 103 \\
\mathrm{mm}-3)\end{array}$ & $(\times 103)$ & $(\times 103)$ & $(\times 103)$ & $(\times 103)$ \\
\hline \multirow[t]{3}{*}{1} & Control & & & & & & & & & & & \\
\hline & Male & $5.94 \pm 0.36$ & $\begin{array}{c}10.98 \pm \\
0.28\end{array}$ & $\begin{array}{c}34.09 \pm \\
1.34\end{array}$ & $\begin{array}{c}54.41 \pm \\
2.21\end{array}$ & $\begin{array}{c}17.74 \pm \\
0.67\end{array}$ & $\begin{array}{c}32.85 \pm \\
0.62\end{array}$ & $\begin{array}{c}464.98 \pm \\
0.65\end{array}$ & $\begin{array}{c}2.06 \pm \\
0.29\end{array}$ & $\begin{array}{c}0.42 \pm \\
0.08\end{array}$ & $\begin{array}{c}6.62 \pm \\
0.06\end{array}$ & $2.02 \pm 0.21$ \\
\hline & Female & $6.26 \pm 0.30$ & $\begin{array}{c}11.14 \pm \\
0.28\end{array}$ & $\begin{array}{c}33.55 \pm \\
1.83\end{array}$ & $\begin{array}{c}53.62 \pm \\
1.37\end{array}$ & $\begin{array}{c}17.42 \pm \\
0.77\end{array}$ & $\begin{array}{c}32.81 \pm \\
0.78\end{array}$ & $\begin{array}{c}510.21 \pm \\
0.65\end{array}$ & $\begin{array}{c}2.69 \pm \\
0.27\end{array}$ & $\begin{array}{c}0.47 \pm \\
0.01\end{array}$ & $\begin{array}{c}0.69 \pm \\
0.02\end{array}$ & $1.83 \pm 0.17$ \\
\hline \multirow[t]{3}{*}{1} & AgNPs & & & & & & & & & & & \\
\hline & Male & $6.74 \pm 0.92$ & $\begin{array}{c}11.64 \pm \\
0.42\end{array}$ & $\begin{array}{c}34.70 \pm \\
1.72\end{array}$ & $\begin{array}{c}55.69 \pm \\
2.54\end{array}$ & $\begin{array}{c}17.61 \pm \\
0.74\end{array}$ & $\begin{array}{c}31.44 \pm \\
0.78\end{array}$ & $\begin{array}{c}516.6 \pm \\
69.09\end{array}$ & $\begin{array}{c}2.40 \pm \\
0.40\end{array}$ & $\begin{array}{c}0.39 \pm \\
0.03\end{array}$ & $\begin{array}{l}0.43 \pm \\
0.042\end{array}$ & $2.2 \pm 0.27$ \\
\hline & Female & $5.66 \pm 0.47$ & $\begin{array}{c}12.15 \pm \\
0.79\end{array}$ & $\begin{array}{c}35.89 \pm \\
1.08\end{array}$ & $\begin{array}{c}54.03 \pm \\
1.02\end{array}$ & $\begin{array}{c}17.27 \pm \\
0.68\end{array}$ & $\begin{array}{c}31.43 \pm \\
0.5\end{array}$ & $\begin{array}{l}479.4 \pm \\
82.07\end{array}$ & $2.2 \pm 0.40$ & $\begin{array}{l}0.41 \pm \\
0.03\end{array}$ & $\begin{array}{l}0.41 \pm \\
0.07\end{array}$ & $1.92 \pm 0.66$ \\
\hline \multirow[t]{3}{*}{7} & Control & & & & & & & & & & & \\
\hline & Male & $6 \pm 0.33$ & $10.5 \pm 0.81$ & $\begin{array}{c}34.26 \pm \\
2.15\end{array}$ & $\begin{array}{c}53.66 \pm \\
1.94\end{array}$ & $\begin{array}{c}17.25 \pm \\
0.81\end{array}$ & $\begin{array}{c}32.533 \pm \\
1.12\end{array}$ & $\begin{array}{l}528.6 \pm \\
128.76\end{array}$ & $\begin{array}{c}2.52 \pm \\
0.65\end{array}$ & $\begin{array}{c}0.33 \pm \\
0.05\end{array}$ & $\begin{array}{c}0.47 \pm \\
0.18\end{array}$ & $1.5 \pm 0.15$ \\
\hline & Female & $5.4 \pm 0.83$ & $\begin{array}{c}10.02 \pm \\
0.79\end{array}$ & $\begin{array}{c}30.61 \pm \\
1.47\end{array}$ & $\begin{array}{c}55.12 \pm \\
2.32\end{array}$ & $\begin{array}{c}17.86 \pm \\
0.43\end{array}$ & $\begin{array}{c}33.5 \pm \\
1.87\end{array}$ & $\begin{array}{c}478.4 \pm \\
79.44\end{array}$ & $\begin{array}{c}2.60 \pm \\
0.42\end{array}$ & $\begin{array}{l}0.46 \pm \\
0.03\end{array}$ & $\begin{array}{l}0.36 \pm \\
0.03\end{array}$ & $\begin{array}{c}1.68 \pm \pm \\
0.17\end{array}$ \\
\hline \multirow[t]{3}{*}{7} & AgNPs & & & & & & & & & & & \\
\hline & Male & $5.56 \pm 0.55$ & $\begin{array}{c}11.30 \pm \\
1.04\end{array}$ & $\begin{array}{c}32.11 \pm \\
2.06\end{array}$ & $\begin{array}{c}53.55 \pm \\
3.00\end{array}$ & $\begin{array}{c}17.75 \pm \\
0.59\end{array}$ & $\begin{array}{c}32.86 \pm \\
0.93\end{array}$ & $\begin{array}{c}515.8 \pm \\
94.26\end{array}$ & $\begin{array}{l}2.52 \pm \\
0.43\end{array}$ & $\begin{array}{c}0.29 \pm \\
0.11\end{array}$ & $\begin{array}{c}0.35 \pm \\
0.11\end{array}$ & $2.1 \pm 0.6$ \\
\hline & Female & $6.71 \pm 0.86$ & $\begin{array}{c}10.62 \pm \\
1.12\end{array}$ & $\begin{array}{c}33.50 \pm \\
2.88\end{array}$ & $\begin{array}{c}47.77 \pm \\
2.01\end{array}$ & $\begin{array}{c}17.70 \pm \\
0.76\end{array}$ & $\begin{array}{c}31.50 \pm \\
1.05\end{array}$ & $\begin{array}{c}497.4 \pm \\
87.22\end{array}$ & $\begin{array}{c}2.14 \pm \\
0.58\end{array}$ & $\begin{array}{c}0.33 \pm \\
0.13\end{array}$ & $\begin{array}{c}0.40 \pm \\
0.09\end{array}$ & $2.2 \pm 0.84$ \\
\hline \multirow[t]{3}{*}{14} & Control & & & & & & & & & & & \\
\hline & Male & $5.92 \pm 0.92$ & $\begin{array}{c}10.90 \pm \\
1.01\end{array}$ & $\begin{array}{c}32.71 \pm \\
1.83\end{array}$ & $\begin{array}{c}53.67 \pm \\
3.12\end{array}$ & $\begin{array}{c}17.92 \pm \\
0.78\end{array}$ & $\begin{array}{c}32.16 \pm \\
0.73\end{array}$ & $\begin{array}{l}477.62 \pm \\
\pm 127.35\end{array}$ & $\begin{array}{c}2.28 \pm \\
0.70\end{array}$ & $\begin{array}{c}0.41 \pm \\
0.10\end{array}$ & $\begin{array}{l}0.40 \pm \\
0.07\end{array}$ & $1.62 \pm 0.23$ \\
\hline & Female & $5.78 \pm 0.74$ & $\begin{array}{c}11.27 \pm \\
1.61\end{array}$ & $\begin{array}{c}35.9 \pm \\
4.06\end{array}$ & $\begin{array}{c}54.34 \pm \\
3.06\end{array}$ & $\begin{array}{c}17.64 \pm \\
0.52\end{array}$ & $\begin{array}{c}32.48 \pm \\
0.87\end{array}$ & $\begin{array}{c}511.18 \pm \\
115.14\end{array}$ & $\begin{array}{c}2.56 \pm \\
0.46\end{array}$ & $\begin{array}{c}0.37 \pm \\
0.08\end{array}$ & $\begin{array}{l}0.37 \pm \\
0.05\end{array}$ & $2.18 \pm 0.55$ \\
\hline \multirow[t]{3}{*}{14} & AgNPs & & & & & & & & & & & \\
\hline & Male & $5.58 \pm 0.74$ & $\begin{array}{c}10.38 \pm \\
1.22\end{array}$ & $\begin{array}{c}29.46 \pm \\
1.69\end{array}$ & $\begin{array}{c}55.22 \pm \\
1.24\end{array}$ & $\begin{array}{c}17.25 \pm \\
0.67\end{array}$ & $\begin{array}{c}31.84 \pm \\
0.63\end{array}$ & $\begin{array}{c}507.49 \pm \\
86.78\end{array}$ & $\begin{array}{c}2.18 \pm \\
0.84\end{array}$ & $0.6 \pm 0.08$ & $\begin{array}{c}0.41 \pm \\
0.07\end{array}$ & $1.50 \pm 0.42$ \\
\hline & Female & $5.8 \pm 0.71$ & $\begin{array}{c}10.58 \pm \\
0.83\end{array}$ & $\begin{array}{c}31.34 \pm \\
1.81\end{array}$ & $\begin{array}{c}52.43 \pm \\
2.23\end{array}$ & $\begin{array}{c}16.91 \pm \\
0.45\end{array}$ & $\begin{array}{c}30.9 \pm \\
0.51\end{array}$ & $\begin{array}{c}486.61 \pm \\
114.78\end{array}$ & $2.2 \pm 0.81$ & $\begin{array}{c}0.38 \pm \\
0.10\end{array}$ & $\begin{array}{c}0.42 \pm \\
0.05\end{array}$ & $1.47 \pm 0.76$ \\
\hline
\end{tabular}

All data are expressed as means \pm SD and were compared with the ANOVA (n=5).

Differences with $P<0.05$ are considered statistically significant.

a) RBC: red blood cell. Hb: hemoglobin concentration. Ht: hematocrit. MCV: mean corpuscular volume. MCH: mean corpuscular hemoglobin. MCHC: mean corpuscular hemoglobin concentration. PLT: platelets. WBC: white blood cell. Lymp: lymphocyte. Mono: monocyte. Granular: granular cells.

Table 4: Biochemical parameters of mice after treatment with colloidal AgNPs Day Treatment.

\begin{tabular}{|c|c|c|c|c|c|c|}
\hline Day & Group & Creatinine & Triglyceride & SGOTa & SGPTb & Total Protein \\
\hline \multirow[t]{3}{*}{1} & Control & & & & & \\
\hline & Male & $0.6 \pm 0$ & $220.4 \pm 6.87$ & $86.52 \pm 17.67$ & $38.83 \pm 14.94$ & $5.06 \pm 0.41$ \\
\hline & Female & $0.6 \pm 0$ & $155.4 \pm 25.01$ & $96.2 \pm 22.62$ & $33.49 \pm 11.77$ & $4.72 \pm 0.29$ \\
\hline \multirow[t]{3}{*}{1} & AgNPs & & & & & \\
\hline & Male & $0.6 \pm 0$ & $211.03 \pm 27.56$ & $95.03 \pm 21.90$ & $31.91 \pm 13.19$ & $5.1 \pm 0.3$ \\
\hline & Female & $0.5 \pm 0.1$ & $179.69 \pm 37.19$ & $106.31 \pm 53.21$ & $35.33 \pm 15.24$ & $4.8 \pm 0.2$ \\
\hline \multirow{2}{*}{7} & Male & $0.5 \pm 0$ & $210.62 \pm 63.03$ & $86.43 \pm 13.62$ & $27.62 \pm 4.65$ & $5 \pm 0.1$ \\
\hline & Female & $0.6 \pm 0.1$ & $147.98 \pm 27.68$ & $66.22 \pm 17.41$ & $15.64 \pm 3.72$ & $5.1 \pm 0.2$ \\
\hline \multirow[t]{3}{*}{7} & AgNPs & & & & & \\
\hline & Male & $0.6 \pm 0.1$ & $197.4 \pm 48.09$ & $128.2 \pm 94.69$ & $89.38 \pm 30.74$ & $5.2 \pm 0.3$ \\
\hline & Female & $0.6 \pm 0.1$ & $142.58 \pm 16.64$ & $109.94 \pm 35.59$ & $19.3 \pm 4.7$ & $5.3 \pm 0.1$ \\
\hline 14 & Control & & & & & \\
\hline
\end{tabular}




\begin{tabular}{|c|c|c|c|c|c|c|}
\hline & Female & $0.6 \pm 0.1$ & $112.2 \pm 18.2$ & $63.4 \pm 21.3$ & $25.2 \pm 8.2$ & $5.2 \pm 0.1$ \\
\hline 14 & AgNPs & & & & & \\
\hline & Male & $0.5 \pm 0.1$ & $232.3 \pm 52.03$ & $81.3 \pm 32.01$ & $27.3 \pm 9.6$ & $5 \pm 0.1$ \\
\hline & Female & $0.6 \pm 0$ & $169.32 \pm 21.3$ & $67.3 \pm 15.5$ & $20.3 \pm 1.5$ & $5.2 \pm 0.1$ \\
\hline
\end{tabular}

All data are expressed as means \pm SD and were compared with the ANOVA $(\mathrm{n}=5)$.

Differences with $P<0.05$ are considered statistically significant.

a) SGOT: Serum Glutamic Oxaloacetic Transaminase.

b) SGPT: Serum Glutamic Pyruvic Transaminase.

Table 5: Zone of inhibition.

\begin{tabular}{|c|c|c|c|}
\hline Name of the bacterial species & $\begin{array}{c}\text { Amount of silver } \\
\text { nanoparticles } \\
\mathbf{1} \mathbf{m g} / \mathbf{m l}\end{array}$ & $\begin{array}{c}\text { Zone of inhibition } \\
\text { Silver nanoparticles }\end{array}$ & $\begin{array}{c}\text { Zone of inhibition } \\
\text { Standard drug }\end{array}$ \\
\hline \multirow{2}{*}{ E. coli } & $10 \mu \mathrm{l}$ & $5 \pm 0.03$ & $20 \mathrm{~mm}$ \\
& $25 \mu \mathrm{l}$ & $7.2 \pm 0.10$ \\
\hline & $50 \mu \mathrm{l}$ & $8 \pm 0.02 \mathrm{~mm}$ & \\
\hline & $10 \mu \mathrm{l}$ & $11 \pm 0.05 \mathrm{~mm}$ & $19 \mathrm{~mm}$ \\
\hline & $25 \mu \mathrm{l}$ & $14.22 \pm 0.11$ & $15 \pm 0.14$ \\
\hline & $50 \mu \mathrm{l}$ & $14 \pm 0.11 \mathrm{~mm}$ & $18 \mathrm{~mm}$ \\
\hline
\end{tabular}
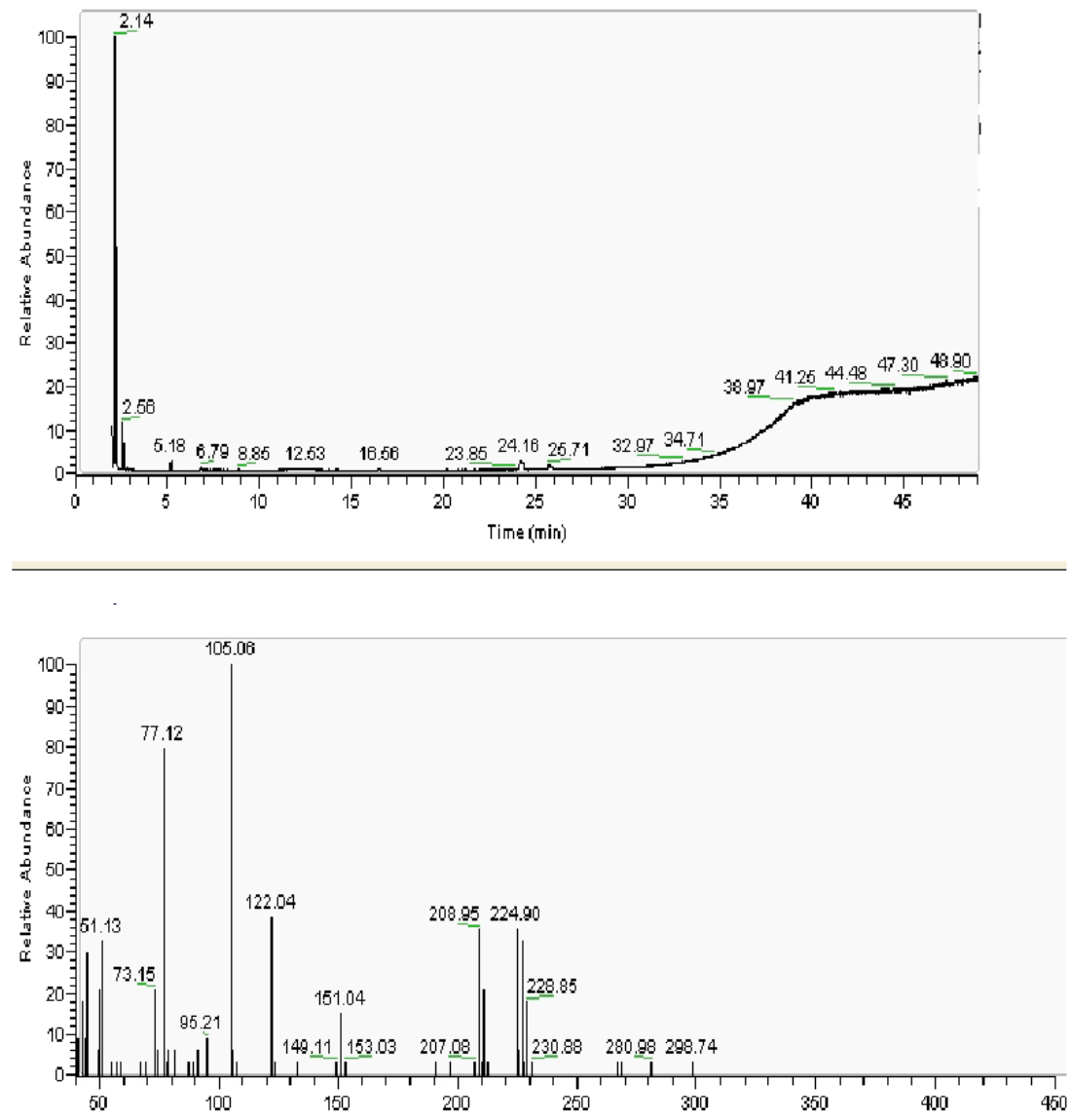

Figure 1: GC-MS analysis of active phytocomponents of $S$ Asoca bark extract. 
nanoparticles [Figure 2D]. Further increase in temperature (up to $65^{\circ} \mathrm{C}$ ), a red-shift appeared from $433 \mathrm{~nm}$ to $455 \mathrm{~nm}$ and this is due to the increase in AgNPs size. The temperature dependent increase in the peak intensity supports temperature controlled nanosilver synthesis. Depending on the size of the nanoparticle, the sharpness in the absorbance peak can be determined, as at higher temperature particle size may be smaller that results in sharpness of the plasmon resonance band of AgNPs [44,45]. Inter-particles dipolar interactions, responsible for clustering, are believed to increase with thermally induced surface layer spin. This agglomeration is thermally reversible up to a critical temperature after which thermal energy overcomes dipolar interactions. Initially due to the reduction in aggregation of the growing nanoparticles, the size was reduced whereas increase in temperature beyond $65^{\circ} \mathrm{C}$ induces crystal growth around the nucleus resulting in a decrease in absorption.

\section{Particle size (DLS) analysis}

DLS can be performed to measure the hydrodynamic diameter which gives us information of the inorganic core along with any coating material and the solvent layer attached to the particle as it moves under the influence of brownian motion. The average size of the AgNPs was measured by DLS for colloidal nanoparticles. The size distribution vs. number percentage graph has been shown in Figure 3. The average size for Ag-NPs synthesized by $S$. asoca is $4.5 \mathrm{~nm}$ and size varies from $3 \mathrm{~nm}$ to $10 \mathrm{~nm}$. The particle size was significantly larger and more polydispersed compared to the AFM result. In DLS analysis large sized particles are observed as DLS measured the total size that includes the bio-organic compounds enveloping the core of the Ag NPs. Prathna et al. [46] found the particle size of silver nanoparticles in the order of techniques DLS > AFM > TEM > XRD. Sometime various forces of interaction in the solution such as vanderwaals can be the reason behind the large particle size. Differences in sample preparation as well as the poly dispersity of the sample cause differences in the particle sizes and that can be determined using the microscopic techniques (as determined by DLS). Based on the instrument response to particle mass, numbers, volume, and optical property, many techniques have been evolved for different size averages. But it is different in case of biological process of synthesis which produces polydisperse particles. However a great degree of caution is required during the measurement of size of biologically synthesized particles by various techniques and it is important to compare for determination of their reactivity for specific applications [47].

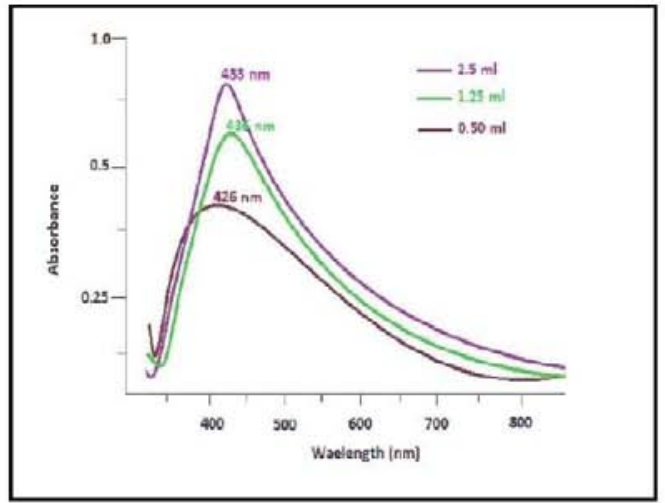

$\mathbf{A}$

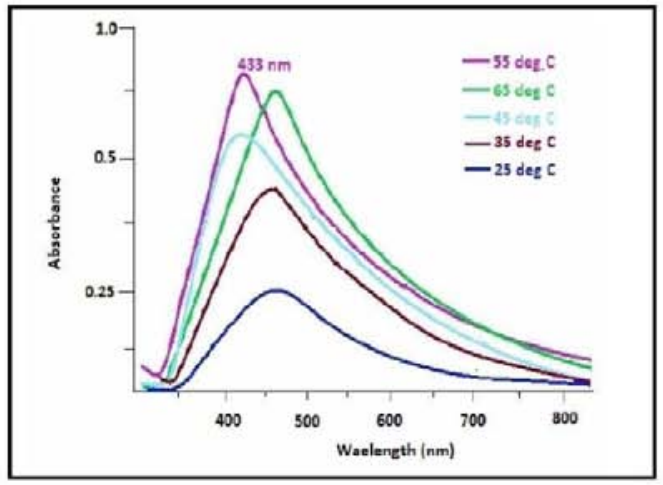

C

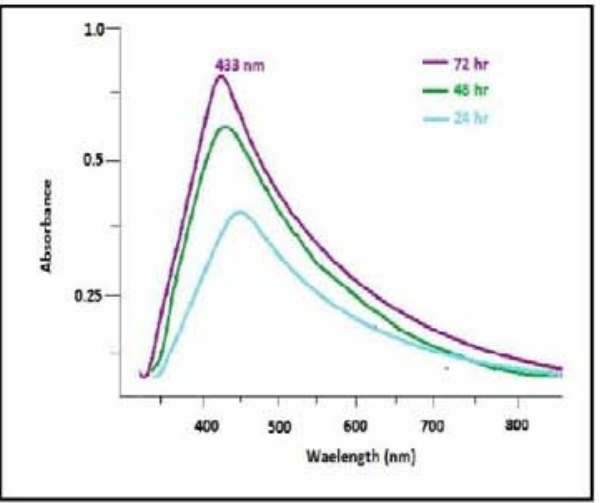

B

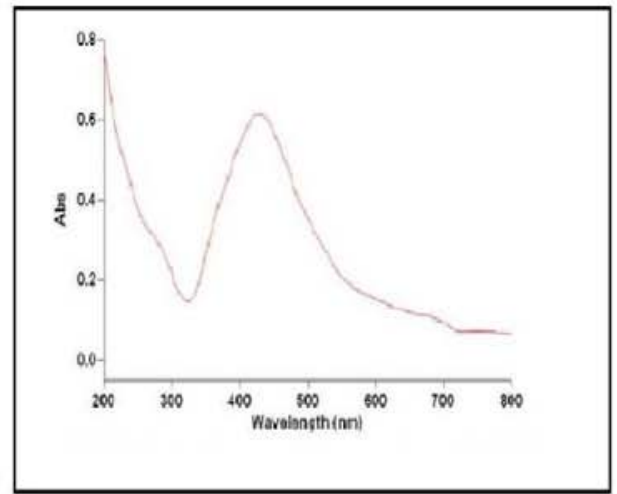

D

Figure 2: UV-visible spectra of Ag-NPs.

(A) Using different molar ratio of $\mathrm{Ag}$ and reductant (bark extract).

(B) Using different time of exposure C. Using different temperature D. UV spectra of final preparation of AgNPs. 


\section{Statistics Graph (1 measurements)}

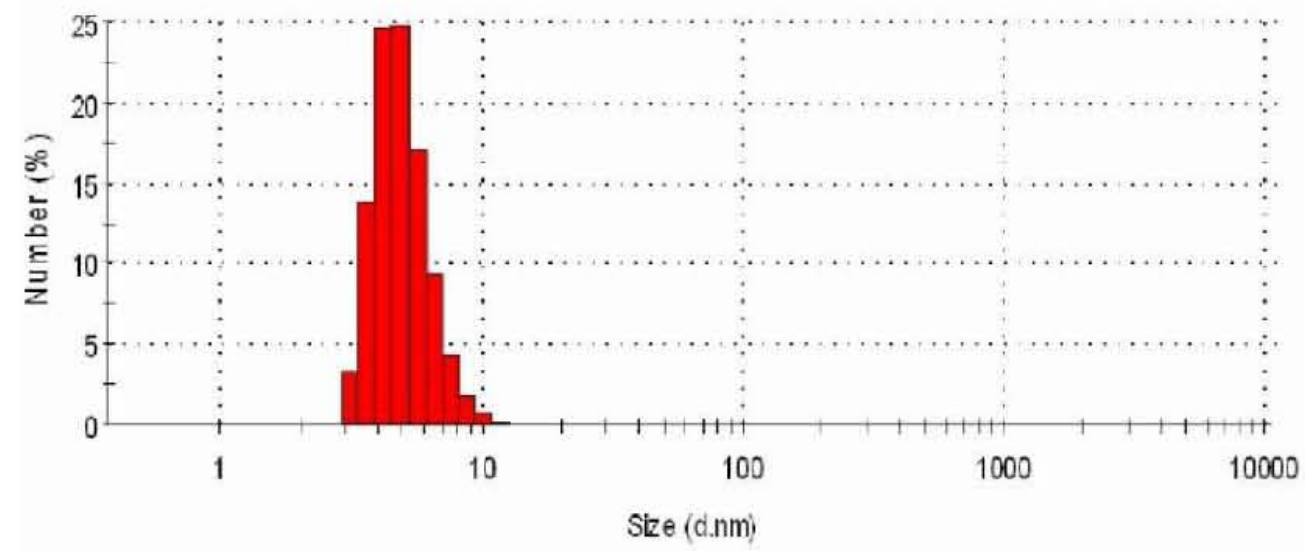

Mean with $+1-1$ Standard Deviation error bar

Figure 3: DLS analysis of Ag-NPs showing percentage distribution of different sized Ag-Nps in the preparation.

\section{AFM analysis}

The results obtained are further corroborated by AFM observations, as shown in Figure 4. From the figure it can be seen that the morphology consists of a mixture of prism and spherical like particles [Fig 4A]. The particle diameter observed at optimum level of $2.5 \mathrm{ml}$ of extract is approx $2.9 \mathrm{~nm}$ in average. The obtained silver nanoparticles exhibited improved dispersibility; and near spherical in shape, The blunt angled nanotriangle was a result of the shrinking process arising from the minimization of surface energy [Figure 4A] [48]. The presence of large quantity of extract causes strong interaction between protective biomolecules and surfaces of nanoparticles preventing nascent silver nanocrystals from sintering. With larger quantities of extract, the interaction is increased, leading to size reduction of spherical nanoparticles [Figure 4B].

\section{Effect of S. asoca bark extract on the stability of silver nanoparticles}

It is important to measure the Zeta Potential (ZP) for the stipulation of the surface charge and stability of the synthesized silver nanoparticles. Ag NPs demonstrate lower ZP value at lower concentration of the extract, whereas higher values were obtained at higher concentration of the extract. In overall, the results of zeta potential value for silver nanoparticles obtained is $-23.2 \mathrm{mV}$ [Figure 5] indicating the stability of the synthesized nanoparticles. So from this it can be concluded that the silver nanoparticles got a negative zeta potential and the particles are fairly stable due to the electrostatic repulsion [49], because low negative values of $\xi$-potential indicate instability of the particles. In our study, the time dependence of the zeta potential on the course of measurement was not observed, which indicated that the Ag-NPs colloidal suspensions were reasonably stable. The rich source of metabolites with negatively charged functional groups may possibly responsible for reduction of metal ions and efficient stabilization of synthesized nanoparticles at natural conditions ( $\mathrm{pH}$ close to 8).

\section{FTIR analysis}

FTIR were performed to identify the biomolecules for capping and efficient stabilization of the metal nanoparticles synthesized by Saraca asoca bark extract. The FTIR spectrum of silver nanoparticles [Figure 6] showed that the band at $3367 \mathrm{~cm}^{-1}$ corresponds to $\mathrm{O}-\mathrm{H}$ alcohols and phenols. The peak at 2926.05 $\mathrm{cm}^{-1}$ corresponds to $\mathrm{CH}$ stretch. The assignment at $1614.80 \mathrm{~cm}^{-1}$ corresponds to $\mathrm{N}-\mathrm{H}$ band primary amines. The peak at 1384.32 $\mathrm{cm}^{-1}$ corresponds to $\mathrm{C}-\mathrm{N}$ stretching of aromatic amine group and the bands observed at $1112.05,1055.42 \mathrm{~cm}^{-1}$ corresponds to C-O stretching alcohols, carboxylic acids, ethers and esters. Therefore the synthesized nanoparticles were surrounded by proteins and other metabolites such as terpenoids having functional groups of alcohols, ketones, aldehydes and carboxylic acids.

From the analysis of FTIR studies we also confirmed that the carbonyl group from the amino acid residues and proteins has the stronger ability to bind metal surfaces. It was indicated that the metal nanoparticles were protected by the proteins which could possibly capped of silver nanoparticles to prevent agglomeration and thereby stabilize the particle size. These studies also suggested that the biological molecules could possibly perform dual functions of formation and stabilization of silver nanoparticles in the aqueous medium.

\section{Evaluation on nanotoxicity: in vivo model}

The colloidal AgNPs in this study can be classified to the category of substances with low toxicity when taken for short periods of time. In the acute oral toxicity test, the mice treated with the dose of $5,000 \mathrm{mg} / \mathrm{kg}$ body weight showed no significant changes in behavior, clinical sign, and percentage of body weight gain, hematological values, serum biochemical values and 


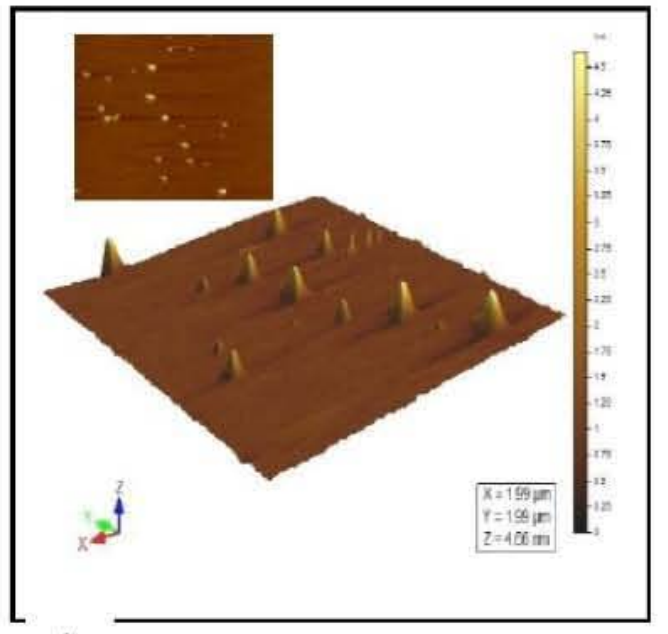

A

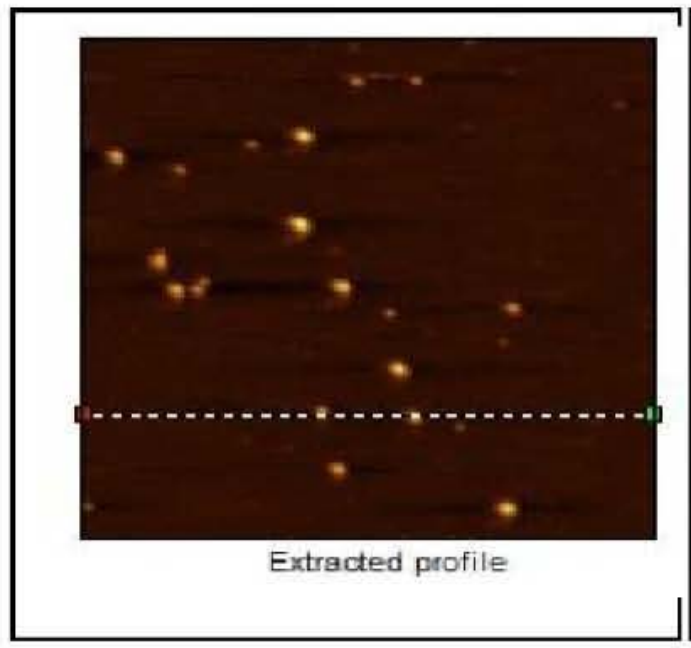

C

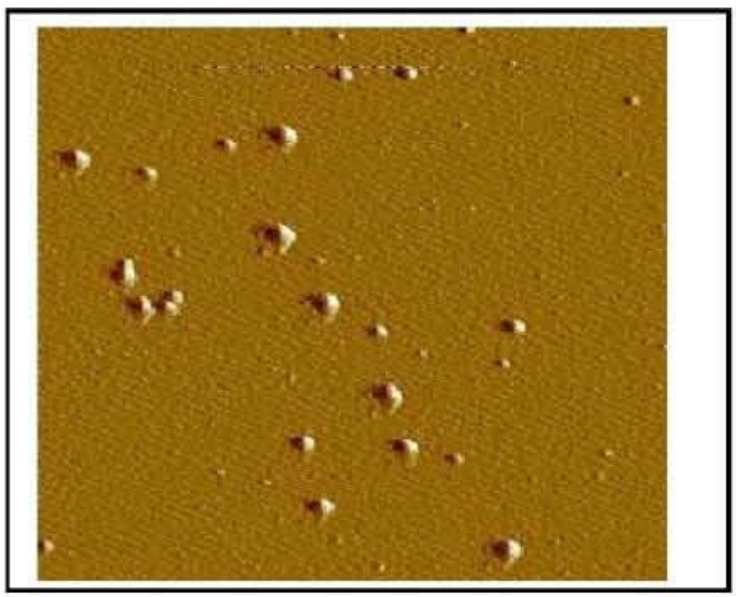

B

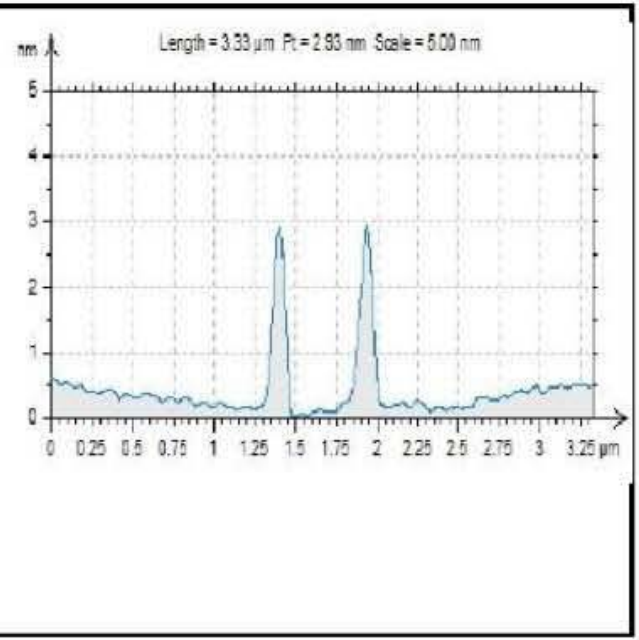

D

Figure 4: AFM image analysis of Ag-NPs. A. surface view and 3D image of Ag-NPs showing prism and round headed form. B. size analysis of the particles coming on the axis indicated.

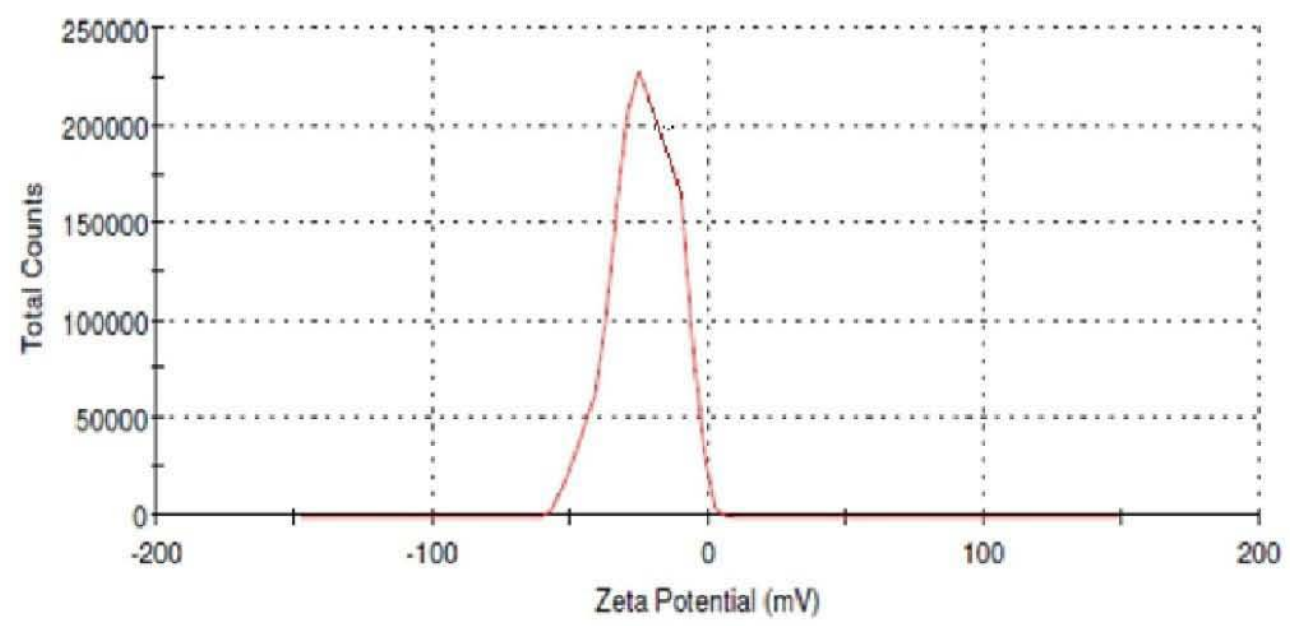

Figure 5: Zeta potential evaluation of Ag-NPs.

Citation: Banerjee P, Nath D (2015) A Phytochemical Approach to Synthesize Silver Nanoparticles for Non-Toxic Biomedical 
consistent pathological evaluation in various organs. In addition, no dead animal was noted during the observation time. The results of the acute oral toxicity study indicated that the LD50 of the colloidal AgNPs is greater than $5,000 \mathrm{mg} / \mathrm{kg}$ according to the OECD (2001) [50] 425 guideline. Substances with LD50 values greater than $5,000 \mathrm{mg} / \mathrm{kg}$ body weight are considered to show low toxicity.

In all acute toxicity tests, no death was recorded in the 14 days of observation period in all control and treated animals. The animals did not show any significant changes in the general appearance during the observation period. There were no significant differences in the percentage of weight gain between the control and treatment groups of both male and female mice given $5,000 \mathrm{mg} / \mathrm{kg}$ of the colloidal AgNPs orally (data not shown).

Hematology and clinical chemistry: The hematological analysis in acute oral toxicity test showed no significant changes of RBC, $\mathrm{Hb} \%, \mathrm{Ht}, \mathrm{MCV}, \mathrm{MCH}, \mathrm{MCHC}$, number of platelets and WBC in the male and female treatment groups compared to the control groups. The leukocyte differential count showed no significant difference between the control and treated groups [Table 3]. There were no significant differences in any of the biochemical parameters examined in either the control or treated group of the male and female mice [Table 4].

Histopathology: Histopathological study showed no significant gross changes in tissue histology. The tissue architecture of major organs such as Liver, Kidney, Spleen and Heart seemed to be similar in both control and treated group of animals.

\section{Assay of bactericidal activity}

The silver nanoparticles synthesized showed the zone of inhibition against all the studied bacteria [Table 5]. The maximum zone of inhibition was found in case of $S$. aureus and lowest was found in P. aeruginosa.

The bactericidal mechanism of silver nanoparticles is only partially understood till date. Based on studies that shows that silver nanoparticles anchor to and penetrate the cell wall of Gram-negative bacteria $[51,52]$ It is reasonable to suggest that the resultant structural change in the cell membrane could cause an increase in cell permeability, leading to an uncontrolled transport through the cytoplasmic membrane, and ultimately cell death. Microorganisms have developed drug resistance over many generations. Different antimicrobial agents based on chemicals show efficacy in therapy; but its use as medical device in prophylaxis in antimicrobial facilities is limited and therefore, an alternative way is needed desperately to overcome the drug resistance of various microorganisms, especially in medical devices, etc. Ag salts and $\mathrm{Ag}^{+}$ions have been used as antimicrobial agents in various fields because of their growth-inhibitory property against microorganisms. But for several reasons these ions have limited usefulness. The main reason is the interfering

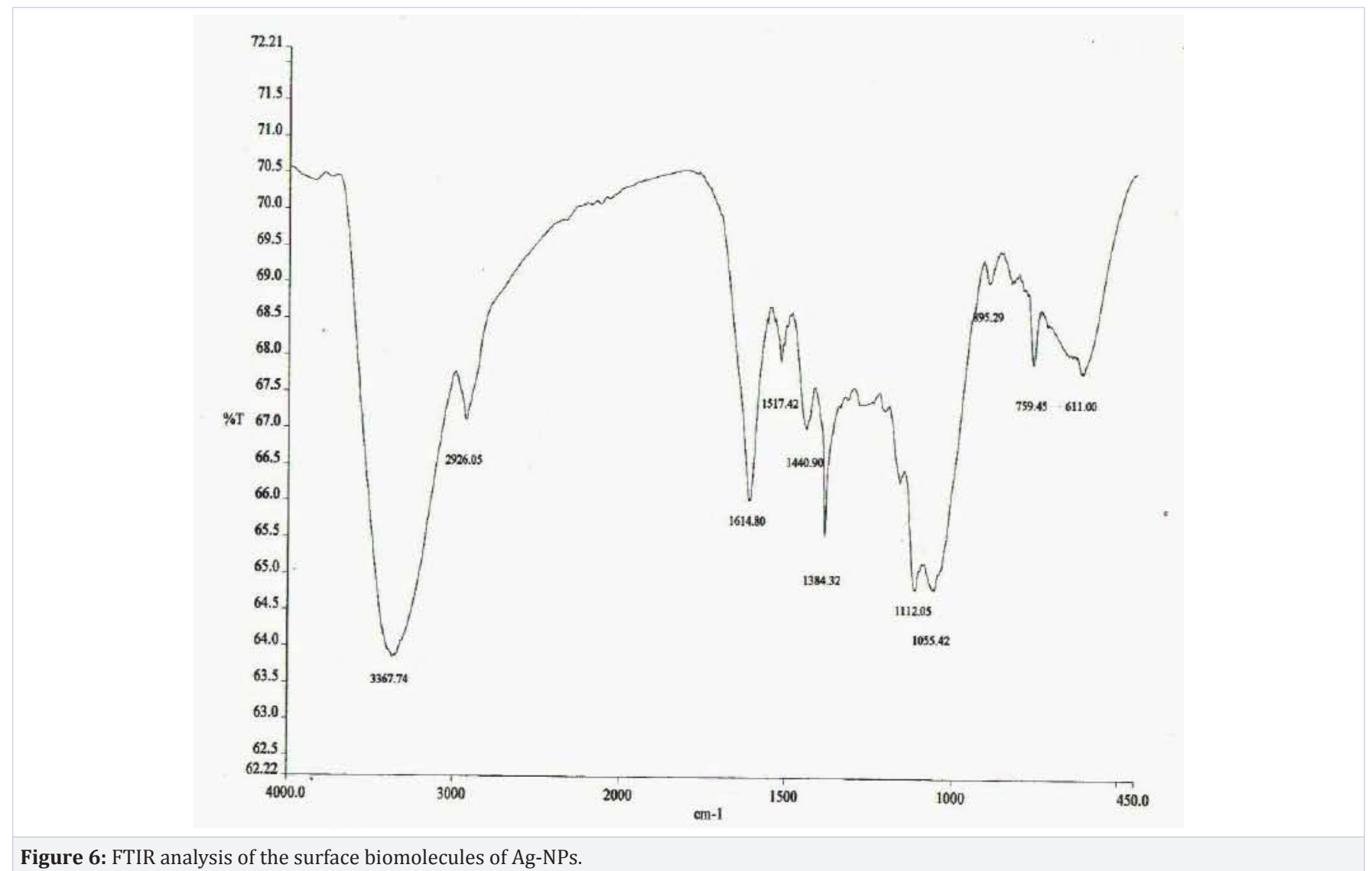

Figure 6: FTIR analysis of the surface biomolecules of Ag-NPs. 
effects of salts and continuous release of enough concentration of $\mathrm{Ag}^{+}$ion from the metal form. These problems can only be solved by the use of Ag nanoparticles. On the other hand, to use Ag nanoparticles in various fields against microorganisms, it is essential to prepare non toxic Ag NPs with cost-effective methods, moreover the mechanism of the antimicrobial activity is of great interest as well. Lee et al. [53] investigated the antibacterial effect of colloidal silver nanoparticles on Staphylococcus aureus and Klebsiella pneumoniae after padding the solution of textile fabrics. Srivastava et,al. [54] studied antibacterial activity on E.coli (ampicillin resistant), E. coli, S. aureus and Salmonella typhi (multi-drug resistant).They reported that the effect was dose dependent and was more pronounced against gram negative organisms in comparison to the gram positive one. They found that the major mechanisms through which silver nanoparticles manifest antibacterial property was either by anchoring or by penetrating the bacterial cell wall and regulating cell signaling by dephosphorylation of the putative key peptide substrate on tyrosine residues. Thus it can be said that Ag nanoparticles synthesis by this herbal, non-toxic and cost effective method of reduction described here have a great promise as antimicrobial agents. Applications of Ag nanoparticles based on these findings may lead to valuable discoveries in various fields of medical biology and antimicrobial systems.

\section{Conclusion}

- The investigation has demonstrated the bioreduction of aqueous $\mathrm{Ag}^{+}$ions by the phytoconstituents of Saraca asoca bark extract. The reduction leads to the formation of silver nanoparticles of well defined dimensions.

- The size and shape of silver nanoparticles could be changed by altering concentration of bark extract as well as temperature which were confirmed by UV-vis spectroscopy and AFM analysis.

- The morphological features represents that the particles synthesized as a mixture of silver nanoprisms and spheres. At lower concentration of extract the mixture shows different shapes of Ag nanoparticles.

- The possible reducing agents are terpenoids and flavonoids. The capping material for stabilization includes proteins present in the bark extract.

- The preliminary in vivo toxicological data reveals that the synthesized nanoparticles have no significant hazardous effect on body system which will be further confirmed on cell toxicity assays using different in vitro cell line model in near future.

- The overall result shows that bark extract of saraca asoca can mediate the biosynthesis of silver nanoparticles efficiently. This green chemistry approach toward the synthesis of silver nanoparticles has many advantages. Possible applications of such eco- friendly and nontoxic nanoparticles in bactericidal, wound healing, drug delivery vehicles and other medical appliances will make this method potentially exciting for the large- scale synthesis of other inorganic nanoparticles.

\section{Acknowledgement}

The authors thankfully acknowledge Professor Rattanlal Hangloo, Vice chancellor, for his interest in this research and PURSE project of DST, Government of India for funding in this research.

\section{References}

1. Bastys V, Pastoriza-Santos I, Rodríguez-González B, Vaisnoras R, LizMarzán L M. Formation of Silver Nanoprisms with Surface Plasmons at Communication Wavelengths. Adv Funct Mater. 2006; 16(6): 766773.

2. Zhang J, Liu Z, Han B, Liu D, Chen J, He J, et al. Novel Method to Synthesize Polystyrene nanospheres Immobilized with Silver Nanoparticles by Using Compressed CO2. Chemistry. 2004; 10: 3531.

3. Dahl JA, Maddux BL, Hutchison JE. Toward greener nanosynthesis. Chem Rev. 2007; 107: 2228-2269.

4. Evanoff DD Jr, Chumanov G. Synthesis and optical properties of silver nanoparticles and arrays. Chemphyschem. 2005; 6: 1221-1231.

5. Kang YS, Kang SW, Kim H, Won J, Kim CK, Char K, et al. Interaction with Olefins of the Partially Polarized Surface of Silver Nanoparticles Activated by $p$-Benzoquinone and Its Implications for Facilitated Olefin Transport. Adv Mater 2007; 19: 475-479.

6. Ma H, Jiao Y, Yin B, Wang S, Zhao S, Huang S, et al. Spontaneous organization of individual silver nanoparticles into one-dimensionally ordered nanostructures. Chemphyschem. 2004; 5: 713-716.

7. Johnson CJ, Zhukovsky N, Cass AE, Nagy JM. Proteomics, nanotechnology and molecular diagnostics. Proteomics. 2008; 8: 715730 .

8. Qiu L, Franc J, Rewari A, Blanc D, Saravanamuttu K. Photolytic formation of $\mathrm{Ag}$ nanoparticles in oligomeric organosiloxanes: new photolithographic routes to metallodielectric microperiodic structures J Mater Chem 2009;19:373-376.

9. Campelo JM, Luna D, Luque R, Marinas JM, Romero AA. Sustainable preparation of supported metal nanoparticles and their applications in catalysis. ChemSusChem. 2009; 2: 18-45.

10. Rondinini S, Aricci G, Krpetic Z, Locatelli C, Minguzzi A, Porta F, Vertova A Fuel cells 2008 (Early View, No. 0), 1.

11. Davis JR. Metals Hand book desk 2nd ed. ASM International, Handbook Committee. San Jose, CA; 1998. P. 658.

12. Lin J, Chen R, Feng S, Pan J, Li Y, Chen G, et al. A novel blood plasma analysis technique combining membrane electrophoresis with silver nanoparticle-based SERS spectroscopy for potential applications in noninvasive cancer detection. Nanomed Nanotech Biol and Med. 2011; 7(5): 655-663. doi: 10.1016/j.nano.2011.01.012.

13. Kim JS, Kuk E, Yu KN, Kim JH, Park SJ, Lee HJ, et al. Antimicrobial effects of silver nanoparticles. Nanomedicine. 2007; 3: 95-101.

14. Brandt O, Mildner M, Egger A E, Groessl M, Rix U, Posch M, et al. Nanoscalic silver possesses broad-spectrum antimicrobial activities and exhibits fewer toxicological side effects than silver sulfadiazine. Nanomed Nanotech Biol Med. 2012; 8(4): 478-488. doi: 10.1016/j. nano.2011.07.005.

15. Mohanty S, Mishra S, Jena P, Jacob B, Sarkar B, Sonawane A. An investigation on the antibacterial, cytotoxic, and antibiofilm efficacy of starch-stabilized silver nanoparticles. Nanomedicine. 2012; 8(6): 916-924. doi: 10.1016/j.nano.2011.11.007. 
16. Nanda A, Saravanan M. Biosynthesis of silver nanoparticles from Staphylococcus aureus and its antimicrobial activity against MRSA and MRSE. Nanomedicine. 2009; 5: 452-456.

17. Gajbhiye M, Kesharwani J, Ingle A, Gade A, Rai M. Fungus-mediated synthesis of silver nanoparticles and their activity against pathogenic fungi in combination with fluconazole. Nanomedicine. 2009; 5(4): 382-386. doi: 10.1016/j.nano.2009.06.005.

18. Fayaz AM, Balaji K, Girilal M, Yadav R, Kalaichelvan PT, Venketesan R. Biogenic synthesis of silver nanoparticles and their synergistic effect with antibiotics: a study against gram-positive and gram-negative bacteria. Nanomedicine. 2010; 6: 103-109.

19. Dar M A, Ingle A, Rai M. Enhanced antimicrobial activity of silver nanoparticles synthesized by Cryphonectria sp. evaluated singly and in combination with antibiotics Nanomedicine. 2013; 9(1): 105-110. doi: 10.1016/j.nano.2012.04.007.

20. Strydom SJ, Rose WE, Otto DP, Liebenberg W, de Villiers MM. Poly (amidoamine) dendrimer-mediated synthesis and stabilization of silver sulfonamide nanoparticles with increased antibacterial activity. Nanomedicine. 2013; 9(1): 85-93. doi: 10.1016/j.nano.2012.03.006

21. Gao H, Liu C, Jeong HE, Yang P. Plasmon-enhanced photocatalytic activity of iron oxide on gold nanopillars. ACS Nano. 2012; 6: 234-240.

22. Kwan K H L, Liu X L, To M K T, Yeung K W K, Ho C M, Wong K K Y Modulation of collagen alignment by silver nanoparticles results in better mechanical properties in wound healing. Nanomed Nanotech Biol and Med. 2011; 7(4): 497-504. doi: 10.1016/j.nano.2011.01.003.

23. Tse C, Zohdy MJ, Ye JY, O’Donnell M, Lesniak W, Balogh L. Enhanced optical breakdown in KB cells labeled with folate-targeted silverdendrimer composite nanodevices. Nanomedicine. 2011; 7(1): 97 106. doi: 10.1016/j.nano.2010.09.003.

24. Stary F, Hans S (1998) The National guides to medical herbs and plants Tiger Books. Int. Plc. UK

25. Park SY, Murphy SP, Wilkens LR, Henderson BE, Kolonel LN Multivitamin use and the risk of mortality and cancer incidence: the multiethnic cohort study. Am J Epidemiol. 2011; 173: 906-914.

26. Marshall AT, Haverkamp RG, Davies CE, Parsons JG, Gardea-Torresdey JL, van Agterveld D. Accumulation of gold nanoparticles in Brassic juncea. Int J Phytoremediation. 2007; 9: 197-206.

27. Gardea-Torresdey JL, Gomez E, Peralta-Videa JR, Parsons JG, Troiani $\mathrm{H}$, Jose Yacaman M. Alfalfa sprouts: a natural source for the synthesis of silver nanoparticles. Langmuir. 2003; 19(4): 1357-1361.

28. Gardea-Torresdey JL, Parsons JG, Dokken K, Peralta-Videa J R, Troiani $\mathrm{H}$, Santiago P, Jose-Yacaman M, et al. Formation and growth of $\mathrm{Au}$ nanoparticles inside live alfalfa plants. Nano Lett. 2002; 2: 397-401.

29. Shankar SS, Rai A, Ankamwar B, Singh A, Ahmad A, Sastry M. Biological synthesis of triangular gold nanoprisms. Nat Mater. 2004; 3: 482-488.

30. Rai A, Singh A, Ahmad A, Sastry M. Role of halide ions and temperature on the morphology of biologically synthesized gold nanotriangles. Langmuir. 2006; 22: 736-741.

31. Mukunthan KS, Elumalai EK, Patel TN, Murty VR. Catharanthus roseus: a natural source for the synthesis of silver nanoparticles. Asian Pac J Trop Biomed. 2011; 1: 270-274.

32. Satishkumar M, Sneha K, Won SW, Kim S, Yun YS. Cinnamon zeylanicum bark extract and powder mediated green synthesis of nano crystalline silver particles and its bactericidal activity. Colloids Surf B Biointerfaces. 2009; 73(2): 332-338. doi: 10.1016/j. colsurfb.2009.06.005.
33.Suja M, Rajan S, Thirunalasundari T, Jana B, Thenmozhi S. Pharmacognostical and phytochemical studies of An Ayurvedic drug Saraca asoca stem bark. J Pharm Res. 2012; 5(2): 1119-1121.

34.Jana B, Thenmozhi S, Suja M, Rajan S, Thirunalasundari T. Pharmacognostical and phytochemical studies of An Ayurvedic drug Saraca asoca stem bark. J Pharma. 2012; 5(2-5): 1119-1121.

35. Saha S, Mukhopadhyay MK, Ghosh PD, Nath D. Effect of Methanolic Leaf Extract of Ocimum basilicum L. on Benzene-Induced Hematotoxicity in Mice. Evid Based Complement Alternat Med. 2012; 2012:176385. doi: $10.1155 / 2012 / 176385$.

36. Witthawaskul P, Panthong A, Kanjanapothi D, Taesothikul T, Lertprasertsuke N. Acute and subacute toxicities of the saponin mixture isolated from Schefflera leucantha Viguier. J Ethnopharmacol. 2003; 89: 115-121.

37. Becerro MA, Lopez NI, Turon X, Uriz MJ. Antimicrobial activity and surface bacterial film in marine sponges. J Exp Mar Biol Ecol. 1994; 179(2): 195-205.

38. Saxena A, Tripathi RM, Singh RP. Biological Synthesis of silver nanoparticles by using Onion (Allium cepa) extract and their antibacterial activity. Dig J Nanomater Bios. 2010; 5(2): 427-432.

39. Vigneshwaran N, Kathe AA, Varadarajan PV, Nachane RP, Balasubramanya RH. Biomimetics of silver nanoparticles by white rot fungus, Phaenerochaete chrysosporium. Colloids Surf B Biointerfaces. 2006; 53: 55-59.

40. Khandelwal N, Singh A, Jain D, Upadhyay MK, Verma HN. Green synthesis of silver nanoparticles using Argimone mexicana leaf extract and Evaluation of their antimicrobial activities. Dig J Nanomater Bios. 2010; 5: 483-489.

41.Vaidyanathan R, Kalishwaralal K, Gopalram S, Gurunathan S. Nanosilver--the burgeoning therapeutic molecule and its green synthesis. Biotechnol Adv. 2009; 27: 924-937.

42. Amendola V, Meneghetti M. Size evaluation of Gold Nanoparticles by UV-vis Spectroscopy. J Phys Chem C. 2009; 113(11): 4277-4288.

43. Haiss W, Thanh NT, Aveyard J, Fernig DG. Determination of size and concentration of gold nanoparticles from UV-vis spectra. Anal Chem. 2007; 79: 4215-4221.

44. Goia DV. Preparation and formation mechanisms of uniform metallic particles in homogeneous solutions. J. Mater. Chem. 2004; 14: 451458.

45. Medina-Ramirez I, Bashir S, Luo Z, Liu JL. Green synthesis and characterization of polymer-stabilized silver nanoparticles. Colloids Surf B Biointerfaces. 2009; 73: 185-191.

46. Prathna TC, Chandrasekaran N, Raichur AM, Mukherjee A. Biomimetic synthesis of silver nanoparticles by Citrus limon (lemon) aqueous extract and theoretical prediction of particle size. Colloids Surf B Biointerfaces. 2011; 82: 152-159.

47. Kasthuri J, Veerapandian S, Rajendiran N. Biological synthesis of silver and gold nanoparticles using apiin as reducing agent. Colloids Surf B Biointerfaces. 2009; 68: 55-60.

48. Ocwieja M, Morga M, Adamczyk Z. Self-assembled silver nanoparticles monolayers on mica-AFM, SEM, and electrokinetic characteristics. J Nanopart Res. 2013; 15(3): 1460.

49. Sujitha M V, Kannan S. Green synthesis of gold nanoparticles using Citrus fruits (Citrus limon, Citrusreticulata and Citrus sinensis) aqueous extract and its characterization Spectrochimica Acta Part A Mol Biomol Spectrosc 2013; 102: 15-23. doi: 10.1016/j. 
saa.2012.09.042.

50. OECD. 2001. Test guideline 425. Acute Oral toxicity test: up and down procedure. In: OECD guidelines for the testing of chemicals. Paris, France: Organization for Economic Cooperation and Development. Organization for Economic Cooperation \& Development (OECD)

51. Morones JR, Elechiguerra JL, Camacho A, Holt K, Kouri JB, Ramírez JT, et al. The bactericidal effect of silver nanoparticles. Nanotechnology. 2005; 16: 2346-2353.
52. Sondi I, Salopek-Sondi B. Silver nanoparticles as antimicrobial agent: a case study on E. coli as a model for Gram-negative bacteria. J Colloid Interface Sci. 2004; 275: 177-182.

53. Lee HJ, Teo SY, Jeong SH. Antibacterial effect of nanosized silver colloidal solution on textile fabrics. 2003. J Mater Sci. 38: 2199-2204.

54.Shrivastava S, Bera T, Roy A, Singh G, Ramachandrarad P, Dash D. Characterization of enhanced antibacterial effects of novel silver nanoparticles Nanotech 2007; 18:225103 